УДК 617.581-089.79:004.942](045)

DOI: http://dx.doi.org/10.15674/0030-59872019178-84

\title{
Comparative analysis of behavior of the «bone - fixator - endoprosthesis» system for I-III type internal hemipelvectomy reconstruction with and without the use of a metal bar
}

\author{
V. Yu. Kostiuk ${ }^{1}$, I. A. Lazarev ${ }^{2}$, A. G. Diedkov ${ }^{1}$, M. V. Skiban ${ }^{2}$ \\ ${ }^{1}$ National Cancer Institute, Kyiv. Ukraine \\ ${ }^{2}$ SI «Institute of Traumatology and Orthopedics NAMS of Ukraine», Kyiv
}

Objective: to study the changes of the biomechanical system «bone - fixator - endoprosthesis» under the loading for internal hemipelvectomy I-III type Enneking with reconstruction of the pelvic ring defect by a metalcement spacer with and without reinforcement with a metal bar. Methods: spatial geometry of the pelvis is reconstructed with the software package «Mimics». Data are obtained by calculating Mises values. Results: the stresses on the screws in the model were not significantly (0.27\%) larger ( $\sigma$ max 132.6 MPa vs. $132.3 \mathrm{MPa}$ in the model without reinforcement) and did not exceed the strength limit. The maximum value of stress on polymethylmethacrylate in both models is localized in the place of contact with the pubic symphysis and is not significantly (0.4\%) higher in the model with the bar ( $\sigma \max -24.7$ and 24.6 MPa, respectively). The maximum values of stress on the sacral bone in both models are defined in the zone of proximal screw installation in the lateral mass of the sacral bone, but $5 \%$ larger in the construction without a bar-10.6 and 10.1 MPa. The maximum permissible loads were: on the sacral bone in a model with a bar of 1.06 body weight, without a bar - 1.01; for polymethylmethacrylate 3.05 and 3.03 body weight respectively; for metal screws 3.44 and 3.43 body weight, respectively. Conclusions: the usage of a metal bar in the system «bone - fixator - endoprosthesis» for internal hemipellectomy type I-III does not change the mechanical strength and stability of the model. The most susceptible to destruction was the lateral area of the sacrum in the place of the proximal screw, which should be strengthened by inserting an additional screw into the upper part of the sacroiliac joint. In the dynamics (walking, running, climbing stairs), the load of the surgery site can be 4 times higher the weight of the body, which due to the linear growth of stress values can lead to the destruction of the structure and requires the usage of additional means of support (crutches, a stick, etc.). Key words: hemipelvectomy, computer mathematical modeling, stress-strain state.
Мета: вивчити поведінку біомеханічної системи «кістка - фіксатор - ендопротез» під навантаженням для внутрішньоі геміпельвектомії I-III типу за Еннекінгом із реконструкиією дефекту тазового кільия металопластмасовим спейсером з $і$ без армування металевою балкою. Методи: просторову геометрію таза реконструйовано з використанням програмного пакета «Мітісs». Дані отримані шляхом розрахунку значень напруження за Мізесом. Результати: напруження на гвинтах у моделі без балки виявилися не значно (0,27 \%) більшими ( $\sigma_{\max }$ 132,6 МПа проти 132,3 МПа у моделі без армування) $і$ не перевищували межу міцності. Максимальне значення напруження на поліметилметакрилаті в обох моделях локалізовано в місиі контакту з лобковим симфізом і не значно (0,4\%) вище в моделі з балкою ( $\sigma_{\max }-24,7$ і 24,6 МПа відповідно). Максимальні значення напруження на крижовій кістиі в обох моделях визначено в ділянці встановлення проксимального гвинта в бокову зону крижової кістки, але на 5 \% більші в конструкції без балки - 10,6 і 10,1 МПа. Максимально допустимі навантаження становили: на крижову кістку в моделі з балкою 1,06 маси тіла, без балки 1,01; для поліметилметакрилату - 3,05 i 3,03 ваги тіла відповідно; для металевих гвинтів - 3,44 і 3,43. Висновки. використання металевої балки в системі «кістка - фіксатор - ендопротез» для внутрішньої геміпельвектоміі типу I-III не змінює механічну міцність і стабільність моделі. Найбільш схильною до руйнування виявилася бокова зона крижової кістки в місиі встановлення проксимального гвинта, яку слід зміинити шляхом введення додаткового гвинта у верхню частину крижово-клубового суглоба. У динамічі (ходьба, біг, підйом сходами) навантаження прооперованоі ділянки може в 4 рази перевищувати вагу тіла, щяо через лінійне зростання значень напружень може спричинювати руйнаиію конструкиї та вимагає застосування додаткових засобів опори (милиці, палиия тощо). Ключові слова: геміпелвектомія, комп'ютерне математичне моделювання, напружено-деформований стан.

Key words: hemipelvectomy, computer mathematical modeling, stress-strain state 


\section{Introduction}

Reconstruction of pelvic bones after internal hemipelvectomy is an important issue for oncological orthopedics [1-3]. To date, there is a fairly wide range of implants to restore the pelvic bone defect, walking function and lower limb support [4-6].

Many authors describe reliability, usability and positive feedback regarding the use of polymethyl methacrylate (bone cement) for pelvic reconstruction after tumorectomy [7-9].

Scientists K. Wiebke Guder et al. [10] restored the integrity of the pelvic ring with a metal-plastic polymethyl methacrylate spacer, metal bar and screws after the tumorectomy of the pelvic bone wing.

I. Miha et al. [9] described a clinical case in which they used polymethylmethacrylate, Schanz rods, total hip joint endoprosthesis, plate and screw for pelvic reconstruction after periacetabular resection. O. E. Vyrva et al. [11] used finite element method to compare the stress-strain state of the "prosthesis-humerus» system in the case of resection in the upper, middle and lower thirds of the humeral $\mathrm{d}$ aphysis and proofed reconstruction system. Also Z. Hua et al. [12] used the finite element method for biomechanical investigation of the half pelvis prosthetic and found that the site of endoprosthesis and pelvic bone contact may become a dangerous part of the structure due to the physical incompatibility of the contacting materials - bone and metal, which leads to increased stresses and deformations. In their view, a more flexible connection can be used in the future to improve the system functioning.

Currently there are no clear standards for reconstructing the pelvic bone defect using a metal-plastic spacer after the internal hemipelvectomy by Enneking [13]. Moreover, there are no fundamental biomechanical studies of the «bone - fixator - endoprosthesis» system behavior under reinforcing the structure with and without a metal bar in oncopathology, which motivated this study.

\section{Materials and Methods}

For the comparative analysis of the pelvic structure reliability 2 methods were selected for reconstruction of the pelvic ring using a metal-plastic spacer.

Method 1. Internal hemipelvectomy by Enneking (type I-III): reconstruction of the pelvic bone defect using a metal-plastic spacer: 4 metal screws are installed in the sacral bone ( 2 units), contralateral pubic bone ( 2 units) and connected with a metal bar for transpedicular fixation, acetabular component of the total hip joint endoprosthesis is located along the bar contour, anatomical contour of the pelvic bone in the reconstruction zone is filled with bone cement.

Method 2. Internal hemipelvectomy by Enneking (type I-III): reconstruction of the pelvic bone defect with a metal-plastic spacer: 4 metal screws are installed in the sacral bone ( 2 units), contralateral pubic bone ( 2 units), acetabular component of the total hip joint endoprosthesis is implanted into the bone cement filling anatomical contour of the pelvic bone.

Spatial geometry of the pelvis with the proximal femur section (fig. 1) was reproduced in automatic and semi-automatic modes using the «Mimics» software package on the basis of the axial scans of the pelvic spiral computed tomography with the proximal part of the femoral bone and the hip joint endoprosthesis on the lesion side obtained on a Toshiba Activion 16 computer tomograph.

Using the «SolidWorks» software package, a simulation «3D-model of the pelvis with a proximal femur part and endoprosthesis on the lesion side» (fig. 2-3) has been designed.

The next step was creation of the simulation models with two variants of defect reconstruction using a metal-plastic spacer consisting of metal screws, bars for transpedicular fixation and polymethyl methacrylate (fig. 4).

Physical and mechanical properties of the model materials

\begin{tabular}{|l|c|c|c|}
\hline \multicolumn{1}{|c|}{ Material } & Jung's Module, Pa & Poisson's coefficient & Strength limits, MPa \\
\hline Cortical layer of the bone & $17.6 \mathrm{e} 9$ & 0.30 & $10-25$ \\
\hline Spongy layer of the bone & $5.0 \mathrm{e} 8$ & 0.28 & $3.5-4.5$ \\
\hline Cartilage & $5 \mathrm{e} 6$ & 0.45 & 590 \\
\hline Titanium BT 16 and BT 6 & $1.12 \mathrm{e} 11$ & 0.32 & 568 \\
\hline Medical steel 17X18H9 & $2 \mathrm{e} 11$ & 0.30 & $35-42$ (up to 70) \\
\hline Polymethyl methacrylate & $8 \mathrm{e} 10$ & 0.30 & - \\
\hline Polyethylene & $1.76 \mathrm{e} 9$ & 0.45 & - \\
\hline
\end{tabular}




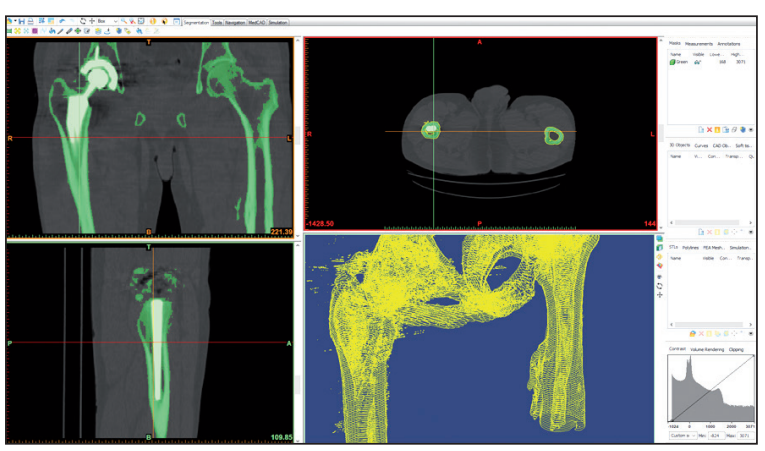

Fig. 1. Reproduction of spatial geometry of the pelvis in polylines

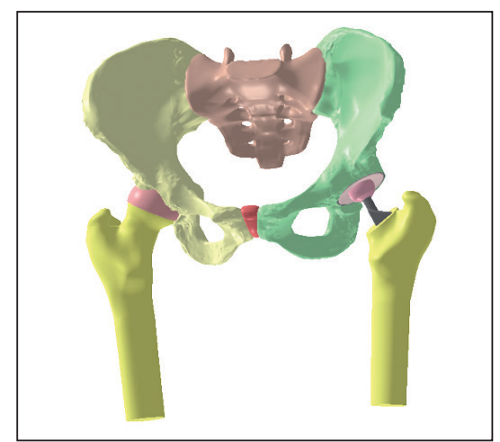

Fig. 2. A simulation model of the pelvis with proximal femur sections and endoprosthesis

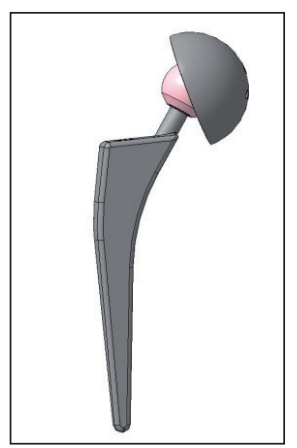

Fig. 3. A 3D-model of the components of the hip joint endoprosthesis

Further calculations were carried out using the finite element method (FE) which allows to investigate the evolution of the deformation process of the elements of the pelvic simulation model, namely, bone tissue, polymethyl methacrylate and fixing metal structures. Simulation models were imported into the «ANSYS» program for calculation of the stressstrain state (SSS) using the FE method. The calculation included physical properties of bone tissue obtained from published sources [14], physical characteristics of materials used in fixators were obtained from their technical documentation (table 1).

As a model loading, an impact of a calculated body weight for an average human body weight of $75 \mathrm{~kg}$ in a standing position is taken including mass-inertial characteristics - the upper half of the body (head, upper limbs, body) is $59.3 \%$ of the total human body
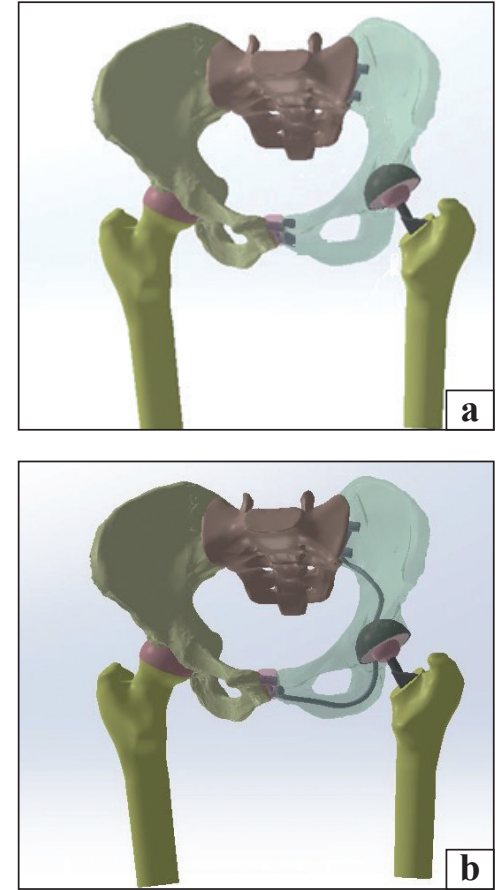

Fig. 4. Simulation models of 2 variants of defect reconstruction using a metal-plastic spacer made of metal screws, a beam for transpedicular fixation and polymethyl methacrylate for I-III type hemipelvectomy with: a) variant 1 without a bar; b) variant 2 with a bar

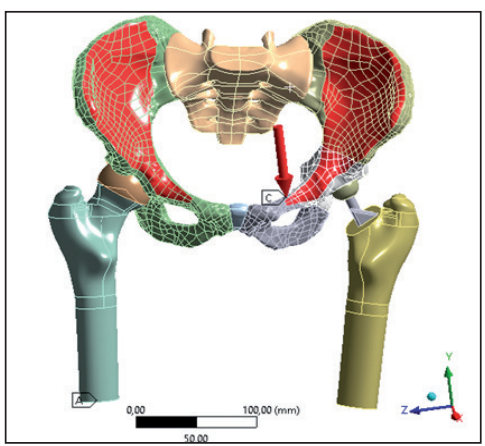

Fig. 5. Limiting conditions (calculation scheme of fixing and loading)

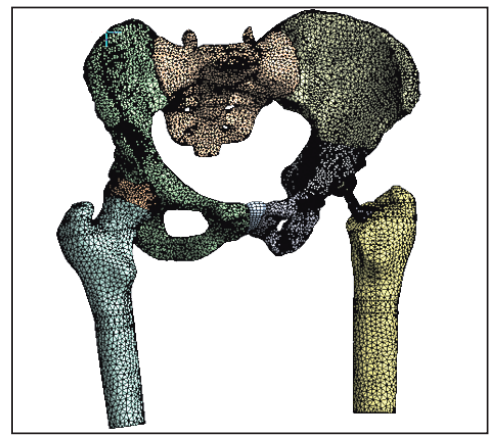

Fig. 6. Models of finite elements

weight [15]. Thus, a force of $750 \mathrm{~N} \times 0.593=445 \mathrm{~N}$ was applied to the model, which was distributed over the entire plane of the pelvic ring (fig. 5). 


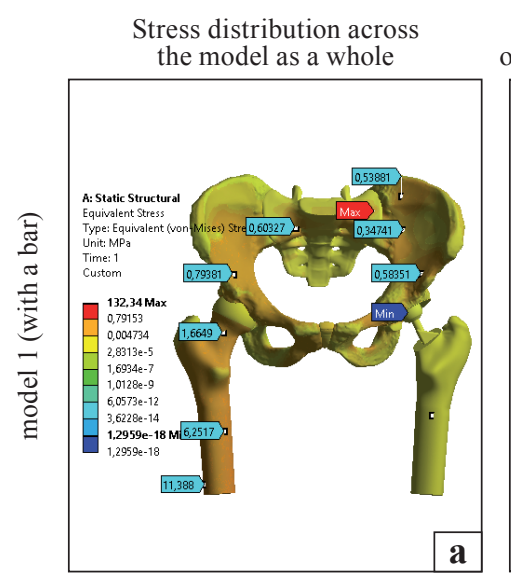
on the contralateral femur the contralateral femoral cartilage

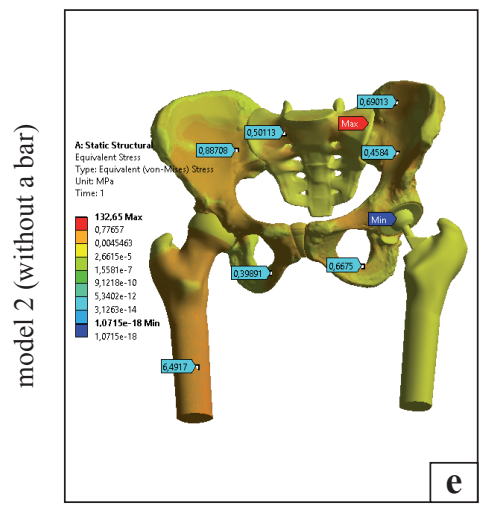

Stress distribution

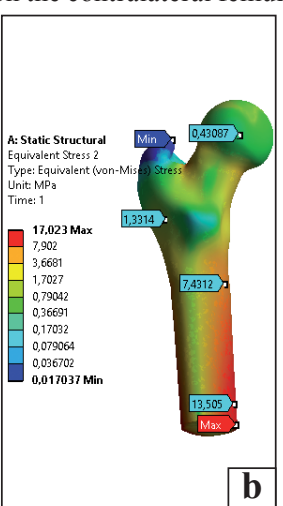

b

Stress distribution on the contralateral femoral cartilage

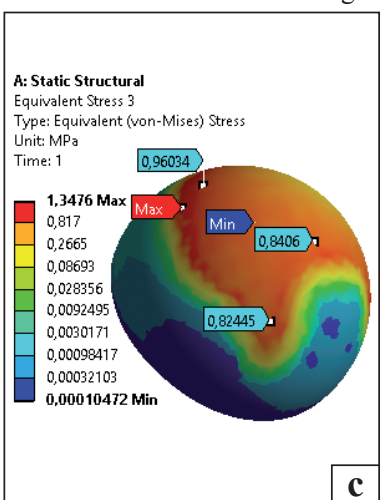

c
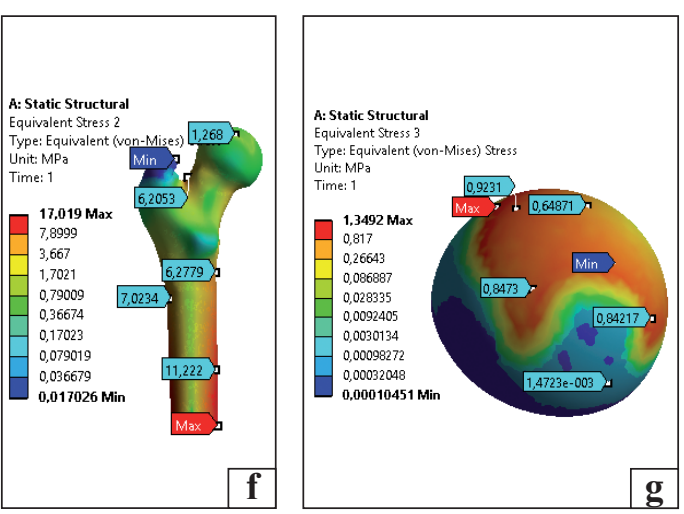

g
Stress distribution on the acetabular contralateral cartilage
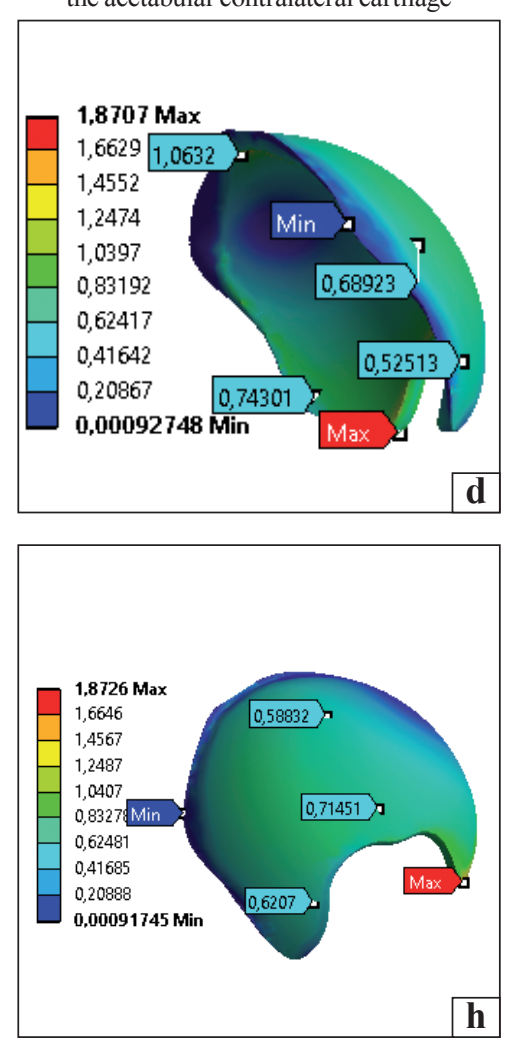

Stress distribution on the femur on the lesion side

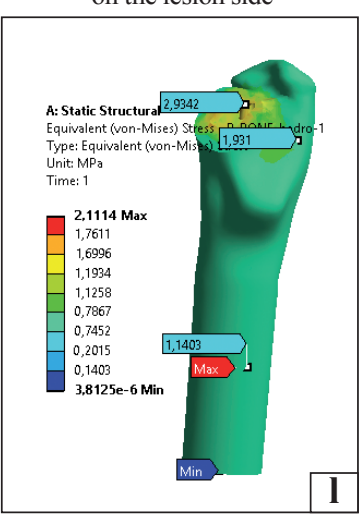

$\mathbf{k}$
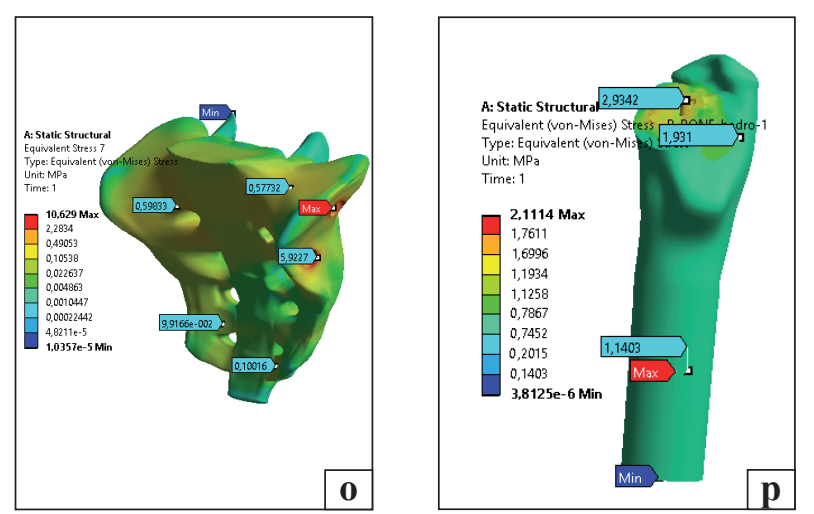
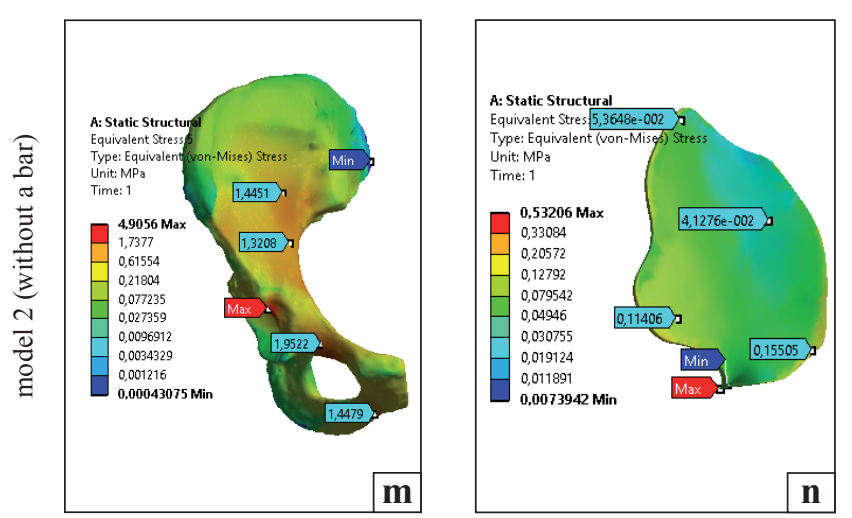

Fig. 7. Distribution of stresses in the models: a) $\sigma_{\max }=132.3 \mathrm{MPa}$; b) $\sigma_{\max }=17 \mathrm{MPa}$; c) $\sigma_{\max }=1.4 \mathrm{MPa}$; d) $\sigma_{\max }=1.9 \mathrm{MPa}$; e) $\sigma_{\max }=132.6 \mathrm{MPa}$; f) $\sigma_{\max }=17 \mathrm{MPa}$; g) $\sigma_{\max }=1.4 \mathrm{MPa}$; h) $\sigma_{\max }=1.9 \mathrm{MPa}$; i) $\sigma_{\max }=4.9 \mathrm{MPa}$; j) $\sigma_{\max }=0.5 \mathrm{MPa}$; k) $\sigma_{\max }=10.1 \mathrm{MPa}$; l) $\left.\sigma_{\max }=2.1 \mathrm{MPa} ; \mathrm{m}\right) \sigma_{\max }=4.9 \mathrm{MPa}$; n) $\sigma_{\max }=0.5 \mathrm{MPa}$; o) $\sigma_{\max }=10.6 \mathrm{MPa}$; $) \sigma_{\max }=2.1 \mathrm{MPa}$; q) $\sigma_{\max }=24.7 \mathrm{MPa}$; r) $\sigma_{\max }=132.3 \mathrm{MPa}$; s) $\sigma_{\max }=4.5 \mathrm{MPa}$; t) $\sigma_{\max }=24.6 \mathrm{MPa}$; u) $\sigma_{\max }=132.6 \mathrm{MPa}$; v) $\sigma_{\max }=4.5 \mathrm{MPa}($ page 1$)$ 

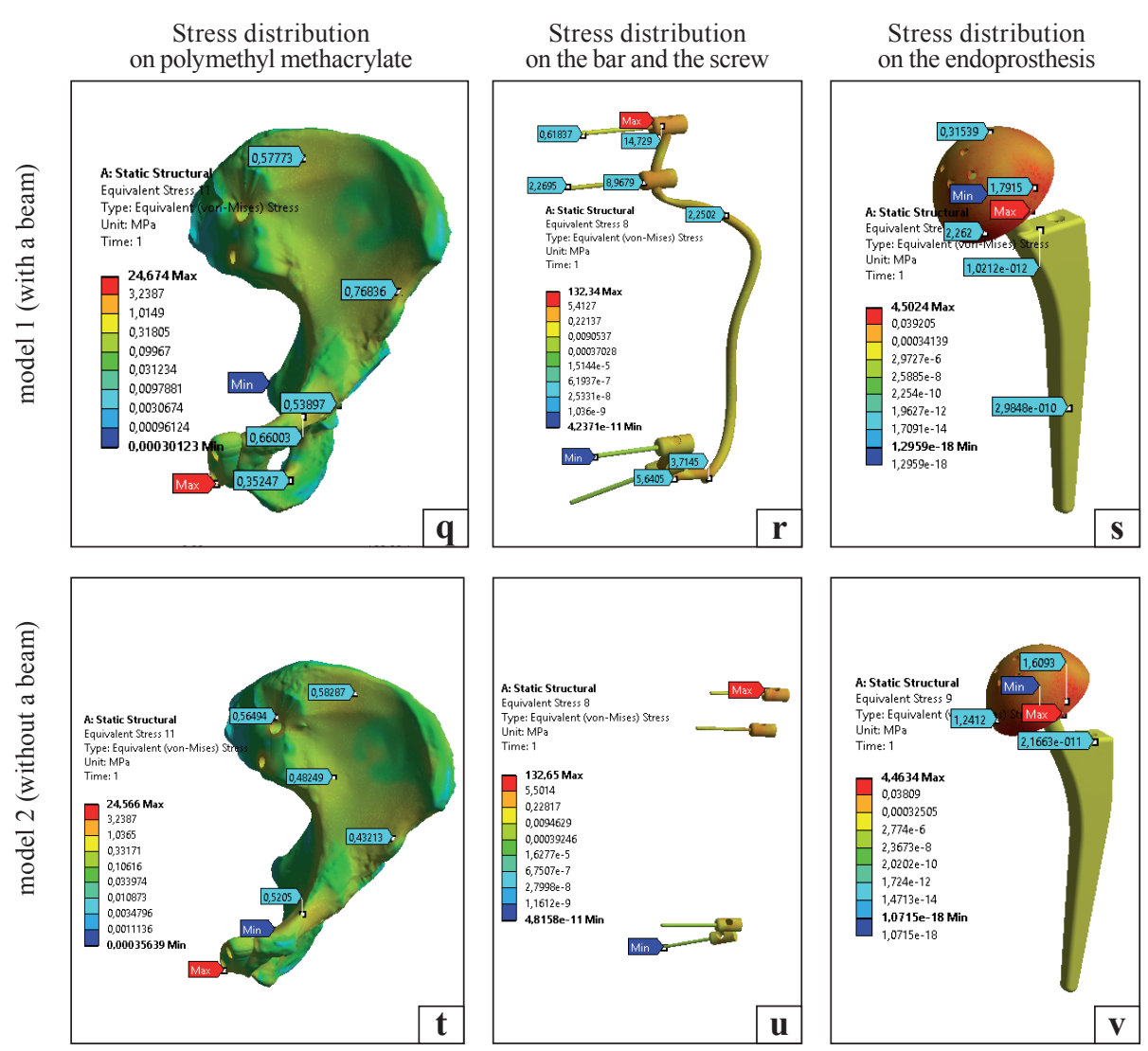

Fig. 7 (page 2)

The FE model that contained an average of 1700000 sites and 1200000 elements (fig. 6) was generated in semi-automatic mode. To increase the accuracy of calculations, the grid was compacted in the contact areas and for the fixation elements and endoprosthesis. The FE grid is represented predominantly by tetrahedral elements (Tetrahedrons), which size does not exceed $2 \mathrm{~mm}$ on the basic model, while in the places of condensation $-0.5-1 \mathrm{~mm}$.

Data obtained by calculation of stress intensity values (by Misis) were selected as key indicators for comparative analysis.

In order to determine the maximum permissible load on the models' elements, a safety factor has been used, depending on the structure of the construction, its operation conditions, accuracy of calculations, loading regime and other factors. For plastic materials, the yield strength should be considered a dangerous stress under static loading. Then

$$
[\sigma]=\frac{\sigma_{0}}{n_{\mathrm{T}}} .
$$

The safety factor value for different types of steels under static load is taken as $\mathrm{n}_{\mathrm{T}}=1.3 \ldots 1.5$.

For brittle materials, the strength limit is a dangerous tension under static loading, and then at (1) the safety factor is taken as $\mathrm{n}_{\mathrm{T}}=2.5 \ldots 3.0$.

Brittle materials are more resistant to compression, while plastic - to stretching. Determination of the stresses magnitude is important since the strength and safety of the structure being designed, as well as the economic aspect - the amount of the material consumed - depend on its correct determination.

There are no clear methods for choosing the safety factors values, since the coefficient is a measure of ignorance of all factors affecting the structure operation. Selection is based on operating experience of similar structures. Each industry has its own standards which determine the permissible safety factors.

In our studies, the safety factor coefficient may be applied to the permissible force under load, since polymethylmethacrylate is considered a brittle material for it, it is better to use a safety factor of 3 , as this structural element is essential to ensure the human biological tissues integrity. Safety factor of 10.5 may be applied for other structural elements, since they may be considered as soft ones.

For our calculations, stress values should be divided by the safety factor coefficient. Moreover, both ultimate strength limit value (yield strength) and load value can be divided by this coefficient. After dividing the load value in the table by this coefficient, it can be argued that the resulting force (weight) is safe for this element or material. 


\section{Results}

According to the research results it was found that the maximum stresses in both models are concentrated on the screws and the bar (fig. 7, r, u).

The stress on screws in model 2 (without the beams) is $0.27 \%$ higher $\left(\sigma_{\max }=132.6 \mathrm{MPa}\right.$ and $\sigma_{\max }=132.3 \mathrm{MPa}$ ) and does not exceed the ultimate strength limits. The tension on the metal bar is mainly concentrated at the sites of contact with the fastening on the screws, and the minimum - in the middle part of the spacer, therefore, it takes on insignificant loads.

The maximum stress values on polymethyl methacrylate (fig. 7, q, t) in both models are localized at the site of contact with the symphysis pubis and are $0.4 \%$ higher in model 1 (with a bar) $\left(\sigma_{\max }=24.7 \mathrm{MPa}\right.$ and $\sigma_{\max }=24.6 \mathrm{MPa}$ ).

The research revealed that the maximum stress values exceeding the ultimate strength limit in both models are concentrated in the area of fixation of the contralateral femur (fig. 7, f, b) $-\sigma_{\max }=17 \mathrm{MPa}$. Given that the areas of maximum stress indices are localized in the places of fixation of the studied models in the middle third of the femur, it can be assumed that using a full model of the femur, these stresses can be evenly distributed throughout its mass and will not exceed the strength limit. That is, these values can be ignored.

Also, stress values exceeding the ultimate strength limit were found in both models on the sacral bone (fig. 7, k, o), namely, in the area of the insertion of the proximal screw in the lateral mass of the sacral bone. These values are $5 \%$ higher in the construction without a bar $\left(\sigma_{\max }=10.6 \mathrm{MPa}\right.$ and $\sigma_{\max }=10.1 \mathrm{MPa}$ ), which does not significantly affect the behavior of the «endoprosthesis - bone» system. However, reduction of stress values and, consequently, the risk of the sacrum destruction can be achieved via introducing an additional screw in the upper part of the sacroiliac joint.

The other elements of the models do not undergo the stresses that exceed strength limit.

Considering strength limits (table 1), there is a risk of integrity violation due to the increased loads in both models (walking, running, climbing stairs), when the stress can increase several times and exceed the ultimate strength limit.

Having used stress value data, maximum loads and material safety factor (table 2), it was found that firstly loading can cause the destruction of the structure in the sacrum area. Maximum permissible load is $5 \%$ higher in model 1 (with a bar) $-\mathrm{F}_{\max }=1.06$ and $\mathrm{F}_{\max }=1.01$ body weight.

Maximum permissible load for polymethyl methacrylate is not significantly higher (1\%) in model 1 (with a bar) $-F_{\max }=3.05$ and $\mathrm{F}_{\max }=3.03$ body weight.

Maximum permissible load for metal screws is not significantly higher $(1 \%)$ in model 1 (with a bar) $\mathrm{F}_{\max }=3.44$ and $\mathrm{F}_{\max }=3.43$ body weight.

The difference between all the parameters studied does not exceed $5 \%$, which suggests that the behavior of the models in general is similar.

Table 2

Stress distribution and maximum permissible loads on each of the model elements

\begin{tabular}{|l|c|c|c|l|c|c|}
\hline \multicolumn{1}{|c|}{ Localization } & $\begin{array}{c}\text { model 1, } \\
\text { MPa }\end{array}$ & $\begin{array}{c}\text { model 2, } \\
\mathrm{MPa}\end{array}$ & $\begin{array}{c}\text { Safety factor, } \\
\mathrm{MPa}\end{array}$ & \multicolumn{1}{|c|}{ Localization } & $\begin{array}{c}\text { model 1, } \\
\mathrm{MPa}\end{array}$ & $\begin{array}{c}\text { model 2, } \\
\text { MPa }\end{array}$ \\
\hline Contralateral femur & 17.00 & 17.00 & 10.77 & Contralateral femur & 281.92 & 281.92 \\
\hline Contralateral femoral cartilage & 1.40 & 1.40 & 3.00 & Contralateral femoral cartilage & 953.57 & 953.57 \\
\hline Contralateral acetabular cartilage & 1.90 & 1.90 & 3.00 & Contralateral acetabular cartilage & 978.09 & 978.09 \\
\hline Contralateral iliac & 4.90 & 4.90 & 10.77 & Contralateral iliac & 978.09 & 978.09 \\
\hline $\begin{array}{l}\text { Contralateral cartilage } \\
\text { of the sacroiliac joint }\end{array}$ & 0.50 & 0.50 & 3.00 & $\begin{array}{l}\text { Contralateral cartilage } \\
\text { of the sacroiliac joint }\end{array}$ & 2670.00 & 2670.00 \\
\hline Sacrum & 10.10 & 10.60 & 10.77 & Sacrum & 474.52 & 452.14 \\
\hline $\begin{array}{l}\text { Cartilage of the sacroiliac joint on } \\
\text { the lesion side }\end{array}$ & - & - & 3.00 & $\begin{array}{l}\text { Cartilage of the sacroiliac joint on } \\
\text { the lesion side }\end{array}$ & - & - \\
\hline Femur on the lesion side & 2.10 & 2.10 & 10.77 & Femur on the lesion side & 2282.21 & 2282.21 \\
\hline $\begin{array}{l}\text { Remains of the iliac bone tissue } \\
\text { on the lesion side }\end{array}$ & - & - & 10.77 & $\begin{array}{l}\text { Remains of the iliac bone tissue } \\
\text { on the lesion side }\end{array}$ & - & - \\
\hline Polymethyl methacrylate & 24.70 & 24.60 & 75.00 & Polymethyl methacrylate & 1351.21 & 1356.71 \\
\hline Beam with screws/screws & 132.30 & 132.60 & 455.00 & Beam with screws/screws & 1530.42 & 1526.96 \\
\hline Endoprosthesis & 4.50 & 4.50 & 455.00 & Endoprosthesis & 44994.44 & 44994.44 \\
\hline
\end{tabular}




\section{Conclusions}

The use of a metal bar in the «bone - fixator endoprosthesis» system with an internal hemipelvectomy of I-III type does not significantly change the mechanical strength and stability of the model.

All the elements of the model - bones, cartilages, polymethyl methacrylate and metal elements withstand 1 body weight ( $75 \mathrm{~kg}$ ) and provide strength and stability of the structure.

The most prone to desrruction element of the models is the lateral mass of the sacrum in the place of insertion of the proximal screw, which should be strengthened in this area and can be achieved via introduction of an additional screw into the upper part of the sacroiliac joint.

In dynamics (walking, running, climbing up the stairs), the load of the operated area can reach the values of 4 body weight, which, due to linear growth of stress values can lead to the structure destruction and requires the use of additional means of support (crutches, stick, etc.).

\section{References}

1. Tumors of the pelvis: complications after reconstruction / A. Hillmann, C. Hoffmann, G. Gosheger [et al.] // Archives of Orthopaedic and Trauma Surgery. - 2003. - Vol. 123 (7). P. 340-344. - DOI: 10.1007/s00402-003-0543-7.

2. Pelvic massive allograft reconstruction after bone tumour resection / D. Campanacci, S. Chacon, N. Mondanelli [et al.] // International Orthopaedics. - 2012. - Vol. 36 (12). P. 2529-2536. - DOI: 10.1007/s00264-012-1677-4.

3. Nieminen J. Orthopaedic reconstruction of complex pelvic bone defects. Evaluation of various treatment methods / J. Nieminen, T. K. Pakarinen, M. Laitinen // The Scandinavian Journal of Surgery. - 2013. - Vol. 102. - P. 36-41. DOI: $10.1177 / 145749691310200108$.

4. Pelvic reconstruction with a structural pelvic allograft after resection of a malignant bone tumor / C. Delloye, X. Banse, B. Brichard [et al.] // Journal of Bone and Joint Surgery. Am. — 2007. — Vol. 89 (3). — P. 579-587. — DOI: 10.2106/ JBJS.E.00943.
5. Barrientos-Ruiz I. Reconstruction after hemipelvectomy with the ice-cream cone prosthesis: what are the short-term clinical results? / I. Barrientos-Ruiz, E. J. Ortiz-Cruz, M. PeleteiroPensado // Clinical Orthopaedics and Related Research. 2017. - Vol. 475 (3). - P. 735-741. — DOI: 10.1007/s11999016-4881-5.

6. Review of hemipelvectomy endoprostheses: Indications and imaging findings / E. A. White, T. J. Learch, G. Matcuk [et al.] // Applied Radiology. — 2013. — Vol. 42 (6). — P. 23.

7. Johnston J. O. Hip reconstruction following in-ternal hemipelvectomy for primary periacetabular sarcomas / J. O. Johnston, R. M. Gray // La Chirurgia degli Organi di Movimento. 1990. - Vol. 75 (1 Suppl). - P. 249-252.

8. Satcher R. L. Jr. Reconstruction of the pelvis after resection of tumors about the acetabulum / R. L. Satcher Jr., R. J. O'Donnell, J. O. Johnston // Clinical Orthopaedics and Related Research. — 2003. - Vol. 409. - P. 209-217. DOI: 10.1097/01.blo.0000057791.10364.7c.

9. Pelvic reconstruction with bone cement and total hip prosthesis after resection of chondrosarcoma. Case report / I. M. Japie, A. Badila, R. Radulescu [et al.] / Rom J. Orthop. Surg. Traumatol. - 2018. - Vol. 1 (1). — P. 7-12. — DOI: 10.1007/ s007760050037.

10. Analysis of surgical and oncological outcome in internal and external hemipelvectomy in 34 patients above the age of 65 years at a mean follow-up of 56 months / W. K. Guder, J. Hardes, G. Gosheger [et al.] // BMC Musculoskelet Disord. — 2015. — Vol. 16. — Article ID: 33. — DOI: 10.1186/ s12891-015-0494-5.

11. Vyrva O. E. Biomechanical study of stress-strain states of the system «endoprosthesis humerus» in terms of tumor resection / O. E. Vyrva, D. O. Mikhanovsky, M. Yu. Karpinsky // Orthopaedics, Traumatology and Prosthetics. - 2015. № 3. - P. 14-20. — DOI: 10.15674/0030-59872015314-20.

12. Biomechanical study on the novel biomimetic hemi pelvis prosthesis / Z. Hua, Y. Fan, Q. Cao, X. Wu // J. Bionic Engineering. - 2013. - Vol. 10 (4). - P. 506-513. DOI: 10.1016/S1672-6529(13)60244-9.

13. Enneking W. E. Resection and reconstruction for primary neo-plasms involving the innominate bone / W. E. Enneking, W. K. Dunham // Journal of Bone and Joint Surgery. 1978. - Vol. 60 (6). - P. 731-746.

14. Kubichek M. Stress strain analysis of knee joint / M. Kubichek, Z. Florian // Engineering Mechanics. — 2009. Vol. 16 (5). - P. 315-322.

15. Zatsiorskiy V. M. Biomehanika dvigatelnogo apparata cheloveka / V. M. Zatsiorskiy, A. S. Aruin, V. N. Seluyanov. Moscow : Fizkultura i sport, 1981. - 143 c.

\title{
ПОРІВНЯЛЬНИЙ АНАЛІЗ ПОВЕДІНКИ \\ СИСТЕМИ «КІСТКА - ФІКСАТОР - ЕНДОПРОТЕЗ» ПІСЛЯ ВНУТРІШНЬОЇ ГЕМІПЕЛЬВЕКТОМІЇ І-ІІІ ТИПУ ТА РЕКОНСТРУКЦІЇ З ВИКОРИСТАННЯМ МЕТАЛЕВОЇ БАЛКИ І БЕЗ
}

\author{
В. Ю. Костюк ${ }^{1}$, I. А. Лазарев ${ }^{2}$, А. Г. Дєдков ${ }^{1}$, М. В. Скибан ${ }^{2}$ \\ ${ }^{1}$ Національний інститут раку, Київ. Україна \\ ${ }^{2}$ ДУ «Інститут травматології та ортопедії НАМН України», Київ \\ $\triangle$ Viktor Kostiuk: doc.kostiuk@gmail.com \\ $\triangle$ Igor Lazarev, PhD in Traumatology and Orthopaedics: ilazarev@ukr.net \\ $\triangle$ Anatolii Diedkov, MD in Traumatology and Orthopaedics: an.dedkov@gmail.com \\ $\bowtie$ Maxim Skiban: maxim-skiban@ukr.net
}

